who possess exceptional clinical performance and have made significant contributions to the specialty with emphasis on the publication of scientific material in peer-reviewed English-language journals. Interested applicants are encouraged to review the membership requirements and guidelines by visiting the AATS Web site at www.aats.org.

\section{Summer Intern Scholarship Applications Now Available}

The American Association for Thoracic Surgery (AATS) Summer Intern Scholarship program introduces the field of cardiothoracic surgery to first- and second-year medical students from North American medical institutions. By pro- viding an opportunity to spend 8 weeks during the summer working in an AATS member's cardiothoracic surgery department, the summer intern scholarship provides medical students with insight into the scientific investigation and study of cardiothoracic surgery.

A grant of $\$ 4,000$ is provided to successful applicants to underwrite their living expenses during the 8 weeks of guidance at the selected host institution. Additionally, all awardees will receive complimentary registration to the Association's 2010 Annual Meeting and postgraduate courses taking place May 1-5 in Toronto, ON, Canada.

For more information and to submit an application, please visit the AATS Web site at www.aats.org. Application Deadline: January 15, 2010.

\section{The Western Thoracic Surgical Association}

\section{Applications for Membership}

Applications for membership in the Association must be received by the Membership Committee Chair no later than March 1, 2010 to be considered at the 2010 Annual Meeting. Applicants must be sponsored by three members of the Association who are not members of the Membership
Committee. Application forms will be issued only to sponsoring members.

Address correspondence to:

Chair, Membership Committee

The Western Thoracic Surgical Association

900 Cummings Center

Suite 221-U

Beverly, MA 01915

978-927-8330; fax: 978-524-8890

wtsa@prri.com

\section{The American Board of Thoracic Surgery}

\section{Notices}

The part I (written) examination was held on December 3. It is planned that this examination will be given at multiple sites throughout the United States using an electronic format. The closing date for registration is August 1 each year. Those wishing to be considered for examination must apply online at www.abts.org.

To be admissible for the Part II (oral) examination, a candidate must have successfully completed the Part I (written) examination.

A candidate applying for admission to the certifying examination must fulfill all the requirements of the Board in force at the time the application is received. Please address all communications to the American Board of Thoracic Surgery, 633 North St Clair Street, Suite 2320, Chicago, IL 60611 (telephone: 312-202-5900).

\section{Requirements for Maintenance of Certification}

Diplomates of the American Board of Thoracic Surgery (ABTS) who plan to participate in the Maintenance of Cer- tification (MOC) process must hold an unrestricted medical license in the locale of their practice and privileges in a hospital accredited by the JCAHO (or other organization recognized by the ABTS). In addition, a valid ABTS certificate is an absolute requirement for entrance into the Maintenance of Certification process. If your certificate has expired, the only pathway for renewal of a certificate is to take and pass the Part I (written) and the Part II (oral) certifying examinations.

The names of individuals who have not maintained their certificate will no longer be published in the American Board of Medical Specialties Directories. Diplomates' names will be published upon successful completion of the Maintenance of Certification process.

The CME requirements are 30 Category I credits earned during each year prior to application. At least half of these CME hours need to be in the broad area of thoracic surgery. Category II credits are not allowed. Interested individuals should refer to the Booklet of Information for Maintenance of Certification for a complete description of acceptable CME credits. Diplomates will be expected to submit verification of CME earned.

Diplomates in the Maintenance of Certification process will need to provide a summary of their major cases performed during the year prior to application. The practice review should not exceed 100 cases. 